\title{
Selecting top fisheries sub-sector in each sub-district for sustainable development of archipelagic region in Indonesia: A hybrid fuzzy-MCDM approach
}

\author{
Wellem Anselmus Teniwut ${ }^{a *}$, Syahibul Kahfi Hamid ${ }^{a}$ and Marvin Mario Makailipessy $^{\mathrm{b}}$
}

${ }^{a}$ Fisheries Agribusiness Study Program, Tual State Fisheries Polytechnic, Indonesia

${ }^{b}$ Fishing Technology Study Program, Tual State Fisheries Polytechnic, Indonesia

\begin{tabular}{l}
\hline C H R O N I C L E \\
\hline Article history: \\
Received May 10, 2019 \\
Received in revised format: \\
May 18, 2019 \\
Accepted June 14, 2019 \\
Available online \\
June 14, 2019 \\
\hline Keywords: \\
MCDM \\
Fuzzy logic \\
Top sub-sector \\
Southeast maluku \\
Fisheries
\end{tabular}

\begin{abstract}
A B S T R A C T
As archipelagic region, an effort to effectively enhance and accelerate the development of each sub-districts to boost the rapid development of Southeast Maluku district in Indonesia cannot happen as long as the local government fails to identify the real potentials and power in fisheries sector of each sub-districts. Identification of each sub-district fisheries top sub-sector has to be based on the human resources, natural resources, infrastructure, current and potential market, current policy of local and central government. A multi-criteria decision making (MCDM) is one of the powerful tools to provide a better result based on complicated factors involved. This paper proposed an integrated MCDM, to tackle the complicated factors in order to provide the best commodities on each sub-districts. Bottom-up concept was used to have a comprehensive result, by combining Fuzzy logic with Analytical Hierarchy Process (AHP) to measure the factors using fuzzy logic with Technique for Order of Preference by Similarity to Ideal Solution (TOPSIS) for determining the top sub-sector in fisheries. For comprehensive assessment of macro factors the study used experts ranging from government, scientists, practitioners to NGOs. On the other hand, for micro factors the survey used field instructor, field officer, fishers and farmers. The results provide a guideline for local and central government to form a better policy regarding the development of each sub-district including farmers, fishers and coastal communities in each subdistrict to focus on commodities that benefited their regions' resources and coastal community's capabilities. By doing so, we hope to contribute on crafting an integrated and collective path on reaching the goal which is the welfare of coastal region.
\end{abstract}

C 2018 by the authors; licensee Growing Science, Canada.

\section{Introduction}

The direction of development in Indonesia starts from rural region being preached by President of Indonesia, Joko Widodo. In regards to the notion of bottom-up development, central government issued guidance in form on National Medium Term Development Plan (RPJMN) as roadmap for nation development in every sector industry, which is currently used for developing Indonesia (Bappenas, 2014). Although the main problem with the roadmap itself is the actual content document was too general and in some cases had no relationship with the current conditions of the regions, there has been an effort to make it relatable with each region by having each local government to form Regional Medium Term Development Plan (RPJMD) based on the national plan. In Southeast Maluku District the RPJMD currently is still working on the road map, therefore the need for an input from every stakeholder regarding the matter is crucial. The policy always change depending on government regime by political background which makes its hard to have a consistent development plan, added with the

\footnotetext{
* Corresponding author

E-mail address: wateniwut@polikant.ac.id (W. A. Teniwut)

C2019 by the authors; licensee Growing Science, Canada. doi: $10.5267 /$ j.dsl.2019.6.001
} 
empirical conditions where most of central and local government often have vague and rhetoric policies on developing regions. In some cases, local government in particular used to have limited knowledge on the right strategy on each part of region and based on their actual regional competitive advantage, which cause the slower regional development (Del Sol \& Kogan, 2007; Havle \& Kilıç, 2019).

Accelerating the development of each region has to be based on each region core competitiveness. Factors namely natural resources, potential market, labor capabilities and infrastructure have to be considered precisely in order to reach the economic and sustainable development of each region (Hill $\&$ Brennan, 2000). There is a fact that there are several factors which directly influence the development of each region and there are also factors that have significant role on the success of regional development such as rapid growth of information technology and technology in general (Zhang, 2009), transportation (Rokicki \& Stępniak, 2018), and growth of population (Shahraki, 2017). By looking into all the factors, the process on identification of the best feature and product of each region should become easier and accurate, which are indicted as the keys for regional economic development (Loizou et al., 2019).

As region consists of small islands and located far from the main islands and cities in Indonesia, Southeast Maluku District posses certain and distinct characteristics especially on its current infrastructure development, human resources capabilities, connectivity, and knowledge on the use of technology. Based on the previous studies from Teniwut et al., (2017a); Teniwut and Teniwut (2018); Hamid et al., (2017); Picaulima et al., (2017); Teniwut et al., (2017b), the infrastructure in general is underdevelopment compared with some big cities in the region also in Kei Islands there is still a huge gap on urban and rural area, coastal communities in the region mostly have low formal educational background where most of their knowledge are based on their experience and knowledge pass by their elders. In addition, the connectivity in the regions also provide a challenge for supply chain.

The more complex variables have to be considered in addition to the empirical challenge in Southeast Maluku District resulted a delicate and complicated problems to be dealt with. Thus, MCDM is a tool that can help us provide decision by considering all factors related. Since 1960s Multi-criteria decision making (MCDM) is one of the most powerful tools for ranking alternative decisions based on a complicated factors (Gou \& Liao, 2007; Wang et al. 2009). The use of MCDM techniques such AHP has been widely used across all research fields, for instance, Ayhan (2020) used Fuzzy AHP for supplier selection; Giamalaki and Tsoutsos (2019) used AHP and GIS for solar power Installation; Teniwut et al. (2019) used AHP and spatial analysis for seaweed information center location; Al Mamun et al. (2019) used Fuzzy AHP to measure water surface quality; Vyas et al. (2019) developed rating system for green building in India, and Hayle et al. (2019) used AHP for error analysis in transatlantic flight.

As mentioned by previous researches about the weakness and advantage of MCDM tools, we need for a combination of MCDM tools to solve a complicated matter. By doing so, the limitation from one tool can be covered by another one. The use of AHP combined with other MCDM tools has been executed previously especially for AHP and TOPSIS, where these two MCDM methods have been used widely to solved various problems in MCDM (Zyoud et al., 2017). AHP was used to determine the preference weights and TOPSIS was used for ranking the best alternatives (Hsieh et al., 2018). As popular as these two methods, Dursun and Karsak (2010) suggested the use of fuzzy logic with MCDM methods to provide a better and more effective results in solving complex problems. Application of Fuzzy AHP and Fuzzy TOPSIS has been used in wide-range of fields, for instance in medical (Büyüközkan \& Çifçi, 2012), Education (Turker et al., 2019), logistic and operational (Sirisawat \& Kiatcharoenpol, 2018), environment development (Singh \& Sarkar, 2019), maritime transportation (Celik \& Akyuz, 2018), bank and financial sector (Mandic et al. 2014), human resources (Chou et al. 2019), construction (Taylan et al. 2014) and electro and electricity (Roy \& Dutta, 2017).

Thus, we consider the empirical condition complicity of the problem on selecting the top commodities on each sub-districts in Southeast Maluku, and focused on using the hybrid fuzzy AHP-TOPSIS to obtain top fisheries sub-sectors in each sub-district in the region. Fuzzy AHP is used to determine the 
weight and Fuzzy TOPSIS was selected to rank the top fisheries sub-sector namely fishing sub-sector, marine culture sub-sector, post-production and processing fisheries, and marine ecotourism. Furthermore, the structure of the study is constructed as follows: the methodology contained study location, data collection and analysis method. The next section is devoted to the result followed by discussion and conclusion.

\section{Material and method}

\subsection{Study Location}

Widely known as the world's largest archipelago country, Indonesia estimated has over 18,100 islands with over $60 \%$ of its people living in small islands region (CTI-CFF, 2009). One of the commonly known archipelagic regions with rich biodiversity and major fish supply in Indonesia is located in Maluku Province, where Kei Islands are among them. The study located in Kei Islands which is Southeast Maluku District. There are two administrative regions in Kei Islands, aside of Southeast Maluku District located in Kei Besar Island and Kei Kecil Islands, there is also Tual City located in Dullah Islands. As seen in Fig. 1, Southeast Maluku geographically is located in $5^{\circ}$ to $6,5^{\circ}$ south latitude and $131^{\circ}$ to $133,5^{\circ}$ east longitude and consists of two largest islands with 25 small islands in the region. The infrastructure and road access is significantly better in Kei Kecil Islands compared with Kei Besar island. This region covers more than $\pm 7.856,70 \mathrm{~km}^{2}$ where almost half of this region is water at \pm $3.180,70 \mathrm{~km}^{2}$ and land area is $\pm 4.676,00 \mathrm{~km}^{2}$. This region is located in average $\pm 100 \mathrm{~m}$ to $115 \mathrm{~m}$ below sea level. In 2016, the population of Southeast Maluku district was 98.684 (Statistic Indonesia, 2017). There are 11 sub-districts in southeast Maluku District, where six sub-districts are located in Kei Kecil islands and five sub-districts are located on larger Kei Besar island with total of 191 villages. Southeast Maluku District is widely known as one of supplier of fish in Indonesia, with high abundant of fish, in addition to good quality of water quality and long white sand beach, the region also supplies large number of seaweed account for 6.455,70 ton in 2017 contributed to IDR 38.734.202.000,- in 2017 (Marine and Fisheries Office of Southeast Maluku District, 2017), and sea cucumber. Most of its people live in coastal regions, as the result the dependency rate to the sea is higher than other regions in Indonesia. Fisheries sector contribute the largest portion on district regional GDP. In 2016, number of fishermen were 5.620 compared with the number of mariculture farmers at 4.652 (Statistic Indonesia, 2017).

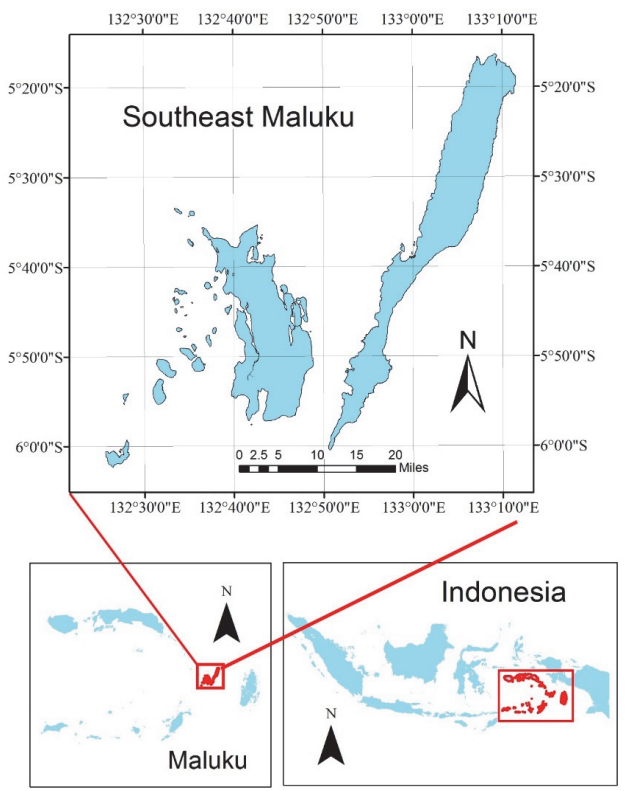

Fig. 1. Study Location 


\subsection{Method}

The research framework of this study is illustrated in Fig. 2, which consists of two parts. In the first part, we calculate the weights for each criterion using fuzzy AHP and in the second part, we use the weights to rank the best alternative with Fuzzy TOPSIS. All MCDM calculation are run using Microsoft Excel (Fig. 2). The experts used on the study are divided into three categories; namely academicians which consist of researchers and lecturers in business and economic field; practitioners including farmers, fishers, entrepreneur related to fisheries commodities; government employee including instructors, fisheries and marine affairs and board of regional development planning. In this paper, we used the computational technique based on the fuzzy numbers defined by Gumus (2009) (See Table 1).

\subsection{Fuzzy AHP}

A conventional AHP has some limitations due to the application, such as the judgmental scale is unbalanced and absence of uncertainty; selection of judgment is subjective, therefore Fuzzy AHP was introduced to tackle the previous limitations. Fuzzy AHP approach was presented by Chang (1996), where pairwise comparisons are established using a nine-point scale and converts experts' preferences into available alternatives such as equally, moderately, strongly, very strongly or extremely preferred. Fig. 3 shows the hierarchical structure of decision problem to select the top commodity in fisheries and marine sector for each sub-district in the Southeast Maluku district.

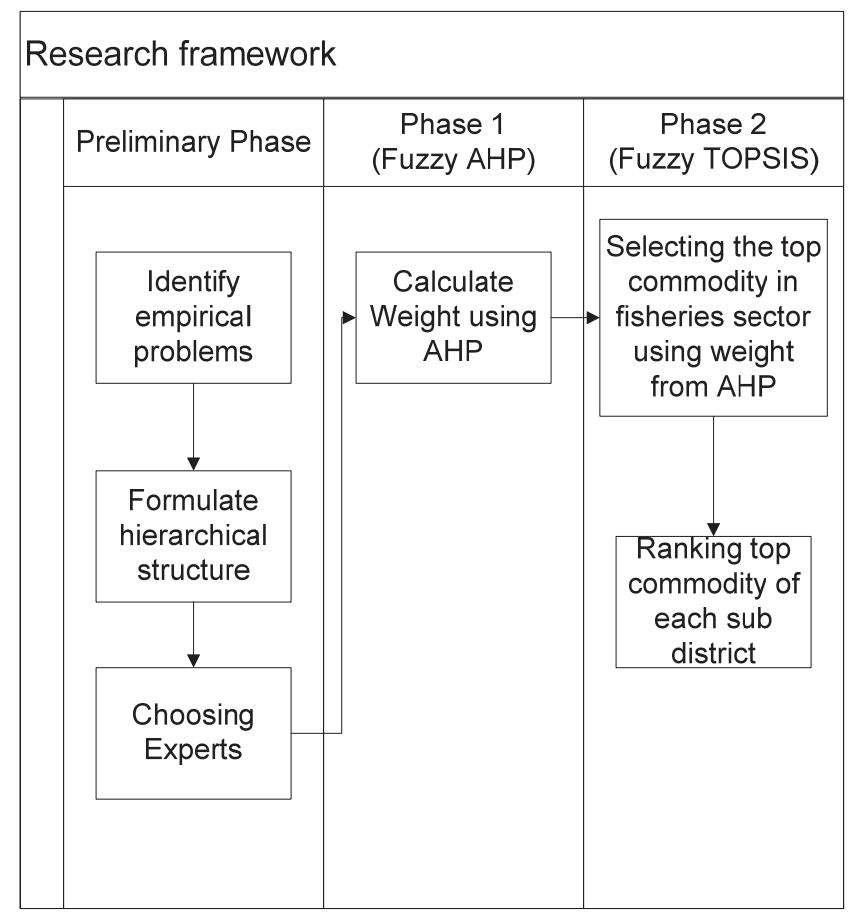

Fig. 2. Proposed research framework

The fuzzy AHP analysis in the study based on Sun (2010), where there are two steps in fuzzy AHP analysis.

Step 1: Pairwise comparison matrix on all criteria by asking which criterion is more important, as shown below matrix $\tilde{A}$ :

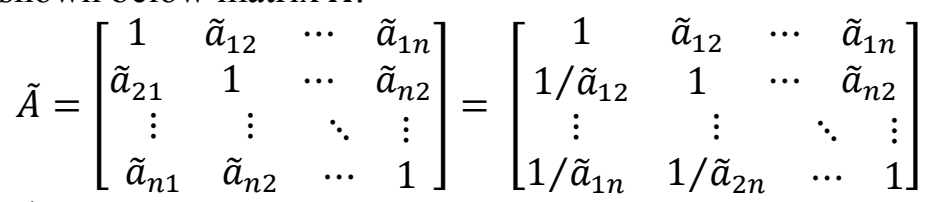

where 
$\bar{a}_{i j}=\left\{\begin{array}{rl}\tilde{9}^{-1}, \tilde{8}^{-1}, \tilde{7}^{-1}, \tilde{6}^{-1}, \tilde{5}^{-1}, \tilde{4}^{-1}, \widetilde{3}^{-1}, \widetilde{2}^{-1}, \tilde{1}^{-1}, \tilde{1}, \widetilde{2}, \widetilde{3}, \widetilde{4}, \widetilde{5}, \widetilde{6}, \widetilde{7}, \widetilde{8}, \widetilde{9} & i \neq j \\ 1 & i=j\end{array}\right.$

Step 2: To define fuzzy geometric mean and fuzzy weights of each criterion, we use geometric mean (Hsieh et al., 2004)

$$
\begin{aligned}
& \tilde{r}_{i}=\left(\tilde{a}_{i 1} \otimes \ldots \otimes \tilde{a}_{i j} \otimes \ldots \otimes \tilde{a}_{i n}\right)^{1 / n} \\
& \widetilde{w}_{i}=\tilde{r}_{i}\left[\tilde{r}_{i} \otimes \ldots \otimes \tilde{r}_{i} \otimes \ldots \otimes \tilde{r}_{n}\right]^{-1}
\end{aligned}
$$

where, $\bar{a}_{i n}$ is fuzzy comparison value of criterion $i$ compared with criterion $n$, thus, $\tilde{r}_{i}$ is geometric mean of fuzzy comparison criterion $i$ to each criterion, $\widetilde{w}_{i}$ is the fuzzy weight of the $i$ th criterion, indicated by TFN, $\widetilde{w}_{i}=\left(L w_{1}, M w_{1}, U w_{1}\right)$. Where $L w_{1}$ represents the lower values, $M w_{1}$ is associated with the middle value and $U w_{1}$ represents the upper values of fuzzy weight of the $i$ th criterion.

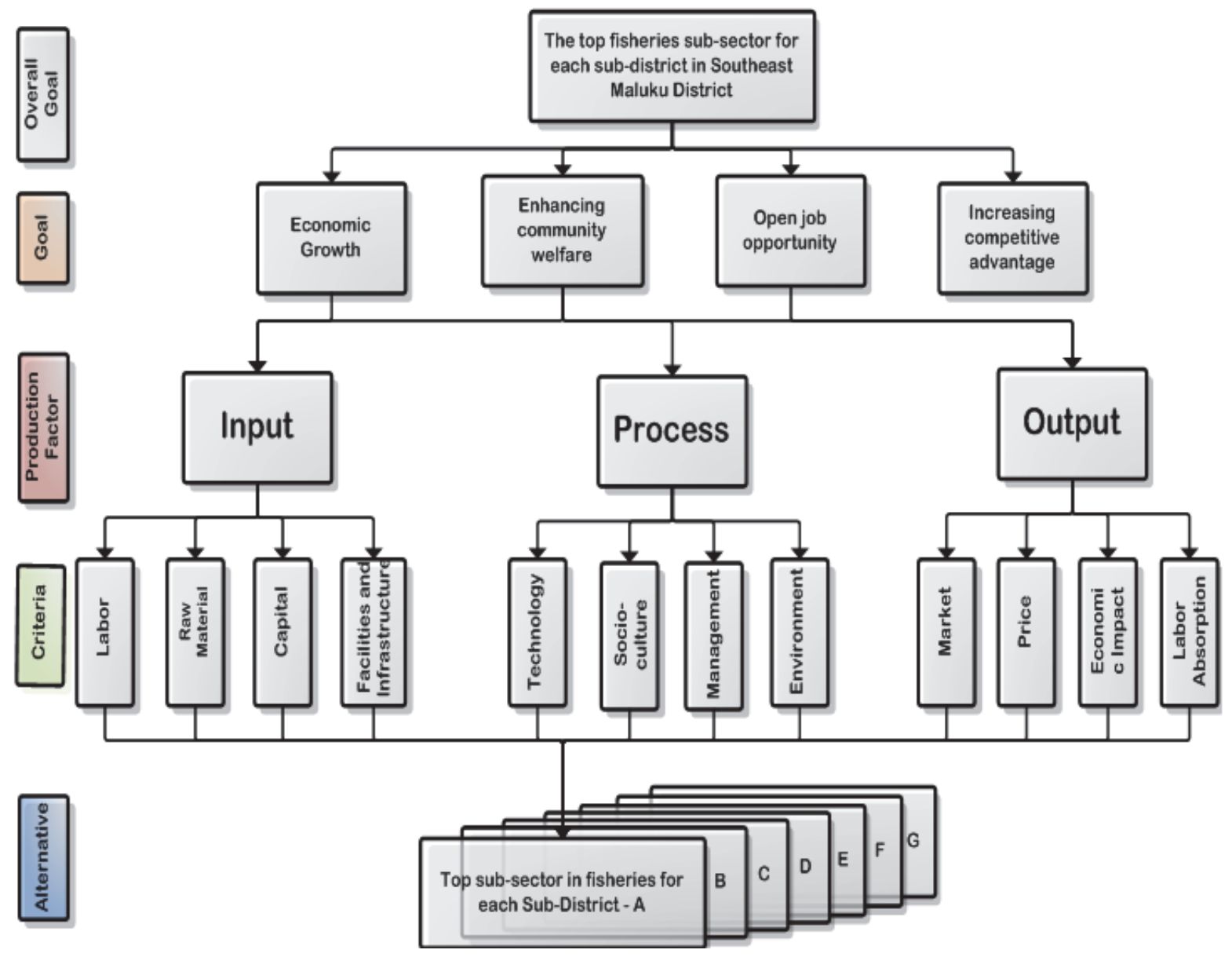

Fig. 3. Hierarchical structure of decision problem.

The consistency on matrix we used is standard consistency ratio (CR) as follows:

$$
C R=\frac{C I}{R I}
$$

where RI is a random index, and $C I$ is consistency index. In addition to determine CI, we used the following equation:

$$
C I=\frac{\lambda_{\max }-n}{n-1}
$$


where $\lambda_{\text {max }}$ is the maximum value of eigenvector; $n$ is the number of criteria. Value of CR is acceptable when CR below 0.1 (Saaty, 1980).

\section{Table 1}

Membership function of linguistic scale

\begin{tabular}{lll}
\hline Fuzzy number & Linguistic & Scale of fuzzy number \\
\hline 9 & Perfect & $(8,9,10)$ \\
8 & Absolute & $(7,8,9)$ \\
7 & Very Good & $(6,7,8)$ \\
6 & Fairly Good & $(5,6,7)$ \\
5 & Good & $(4,5,6)$ \\
4 & Preferable & $(3,4,5)$ \\
3 & Not bad & $(2,3,4)$ \\
2 & Weak Advantage & $(1,2,3)$ \\
1 & Equal & $(1,1,1)$ \\
\hline
\end{tabular}

\subsection{Fuzzy TOPSIS}

TOPSIS is widely used for ranking problems. TOPSIS method has some limitations in capturing the vagueness of data under fuzzy environment (Kannan et al., 2014). Thus, fuzzy TOPSIS method was proposed to solve multi criteria decision making problems to manage with uncertainty in the evaluations of the decision makers (Kannan et al. 2014; Prakash \& Barua, 2015). In fuzzy TOPSIS, the ratings and the weights are defined by the linguistic variable which is then set to fuzzy numbers called TFN. Therefore, the steps of fuzzy TOPSIS method used in this study, according to Sun (2010) and Kannan et al. (2014) can be seen as follow:

Step 1. Determine rating of the linguistic value for criteria and scale used for rating. By doing so, enable to determine weights of evaluation criteria, this study applied fuzzy AHP to find the fuzzy preference weight.

Step 2. Construct the fuzzy performance/matrix for alternatives by considering a group of $k$ decision makers $\widetilde{D}$ containing $m$ alternatives $\left(\mathrm{A}_{\mathrm{m}}\right)$ and $\mathrm{n}$ criteria $\left(\mathrm{C}_{\mathrm{n}}\right)$.

$$
\begin{aligned}
& \begin{array}{llll}
C_{1} & C_{2} & \ldots & C_{n}
\end{array} \\
& \widetilde{D}=\begin{array}{c}
A_{1} \\
A_{2} \\
\vdots \\
A_{m}
\end{array}\left[\begin{array}{cccc}
r_{11} & r_{12} & \ldots & r_{1 n} \\
r_{21} & r_{22} & \ldots & r_{2 n} \\
\vdots & \vdots & \ddots & \vdots \\
r_{m 1} & r_{m 2} & & r_{m n}
\end{array}\right]
\end{aligned}
$$

where $r_{m n}$ is the rating of alternative $A^{m}$ with respect to criterion $C_{n}$. Let $W_{j}=\left(W_{1}, W_{2}, \ldots, W_{n}\right)$ be the relative weight vector of the $n$ criteria that should be equal to 1 .

Step 3. Aggregate fuzzy rating for the solutions. Fuzzy rating of Nth decision maker $\tilde{X}_{a b N}=$ $\left(I_{a b N}, P_{a b N}, u_{a b N}\right)$ where $a=1,2, \ldots, m$ and $b=1,2, \ldots, n$ then the fuzzy aggregated fuzzy rating $\tilde{X}_{a b N}$ of solutions with respect to each criteria is given by $\tilde{X}_{a b N}=\left(I_{a b N}, P_{a b N}, u_{a b N}\right)$, where

$$
a=\min _{N}\left\{l_{a b N}\right\}, b=\frac{1}{N} \sum_{n=1}^{N} p_{a b N}, c=\max _{N} u_{a b N}
$$

Step 4: Normalize the fuzzy-decision matrix. Assume that the decision matrix is $X=\left(x_{i j}\right)_{m x n}$. The decision matrix for $m$ alternatives and $n$ criteria can be normalized as follows,

$$
S=\left[s_{i j}\right]_{m x n}
$$


where

$$
s_{i j} \frac{r_{i j}}{\sqrt{\sum_{i=1}^{m} r_{i j}^{2}}} .
$$

Step 5: Construct the weighted normalized decision matrix.

$$
\begin{aligned}
& \tilde{V}=\left[\tilde{v}_{i j}\right]_{m x n} \quad i=1,2,3, \ldots m \text { and } j=1,2,3, \ldots, n \\
& \text { where } \tilde{V}=\tilde{p}_{i j} \times w_{j}
\end{aligned}
$$

Step 6: Determine the fuzzy positive-ideal solution (FPIS) and fuzzy negative-ideal solution (FNIS) as follows,

$$
\begin{gathered}
A^{+}=\left(\tilde{v}_{1}^{*}, \ldots, \tilde{v}_{j}^{*}, \ldots, \tilde{v}_{n}^{*}\right) \\
A^{-}=\left(\tilde{v}_{1}^{-}, \ldots, \tilde{v}_{j}^{-}, \ldots, \tilde{v}_{n}^{-}\right)
\end{gathered}
$$

where $\tilde{v}_{j}^{*}=(1,1,1) \otimes \bar{w}_{j}=\left(l w_{j}, m w_{j}, u w_{j}\right)$ and $\tilde{v}_{j}^{-}=(0,0,0), j=1,2, \ldots, n$.

Step 7: Calculate the distance of each alternative from FPIS and FNIS. The distances $\left(\bar{d}_{i}^{+}\right.$and $\left.\bar{d}_{i}^{-}\right)$of each alternative from $\mathrm{A}^{+}$and $\mathrm{A}^{-}$can be currently calculated by the area compensation method, computed as follows:

$$
\begin{aligned}
& \bar{d}_{i}^{+}=\sum_{j=1}^{n} d\left(\bar{v}_{i j}, \tilde{v}_{j}^{*}\right), \quad i=1,2, \ldots, m ; j=1,2, \ldots, n \\
& \bar{d}_{i}^{-}=\sum_{j=1}^{n} d\left(\bar{v}_{i j}, \tilde{v}_{j}^{-}\right), \quad i=1,2, \ldots, m ; j=1,2, \ldots, n
\end{aligned}
$$

Step 8: Calculate the closeness coefficient to determine the ranking order of all alternatives once the $\mathrm{d}^{-}$associated with alternative $A i(i=1,2, \ldots, m)$ is calculated by using the following equation:

$$
C C_{i}=\frac{d^{-}}{d^{+}+d^{-}}
$$

Step 9: Find the ranks. Alternatives ranked based on their closeness coefficient to the ideal solution by descending order.

\section{Results and discussion}

The integration of Fuzzy AHP and Fuzzy provide a very systematics structure for decision maker to be able to have a better understanding also have more comprehensive view on all variable related to the matter in order to take a final decision on top fisheries sub-sectors on each sub-districts in Southeast Maluku District in Indonesia. As shown on Table 2 and Table 3, the main goal of selecting a top fisheries sub-sectors in the region based on experts' assessments yields ECW $>0 J O>I C A>E G$. Enhance economic welfare of the community is the main goal to select top fisheries sub-sectors in Southeast Maluku.

\section{Table 2}

Aggregated fuzzy comparison matrix of goal

\begin{tabular}{lllllllllllll}
\hline & \multicolumn{3}{c}{ EG } & \multicolumn{3}{c}{ ECW } & \multicolumn{3}{c}{ OJO } & \multicolumn{3}{c}{ ICA } \\
\hline EG & $(1.00$, & 1.00, & $1.00)$ & $(0.12$, & 0.14, & $0.16)$ & $(0.13$, & 0.15, & $0.18)$ & $(0.25$, & 0.30, & $0.37)$ \\
ECW & $(6.19$, & 7.19, & $8.19)$ & $(1.00$, & 1.00, & $1.00)$ & $(1.45$, & 1.70, & $2.00)$ & $(6.19$, & 7.19, & $8.19)$ \\
OJO & $(5.56$, & 6.60, & $7.63)$ & $(0.50$, & 0.59, & $0.69)$ & $(1.00$. & 1.00, & $1.00)$ & $(5.50$, & 6.52, & $7.53)$ \\
ICA & $(2.73$, & 3.30, & $3.95)$ & $(0.12$, & 0.14, & $0.16)$ & $(0.13$, & 0.15, & $0.18)$ & $(1.00$, & 1.00, & $1.00)$ \\
\hline
\end{tabular}


Table 3

Normalized Matrix and weight of goal

\begin{tabular}{|c|c|c|c|c|c|c|}
\hline & EG & ECW & OJO & ICA & Final Weight & Rank \\
\hline EG & 0.06 & 0.07 & 0.05 & 0.02 & 0.05 & 4 \\
\hline ECW & 0.40 & 0.53 & 0.57 & 0.48 & 0.51 & 1 \\
\hline OJO & 0.36 & 0.32 & 0.33 & 0.43 & 0.37 & 2 \\
\hline ICA & 0.18 & 0.07 & 0.05 & 0.07 & 0.09 & 3 \\
\hline
\end{tabular}

Moreover, as it is shown on Tables 4-11 we can see the result of fisheries production factors' weights. The study uses three basic production stream from input, proses to output, where factor production to economic growth were process $>$ output $>$ input (Tabel 5). For factors production to enhance economic welfare, open job opportunity and increase competitive advantage were all shown the same results i.e. output $>$ process $>$ input (Tabel 7; Table 9; Table 11).

Table 4

Aggregated fuzzy comparison matrix of factor production to goal EG

\begin{tabular}{lccccccccc}
\hline & \multicolumn{3}{c}{ Input } & \multicolumn{3}{c}{ Process } & \multicolumn{3}{c}{ Output } \\
\hline Input & 1.00 & 1.00 & 1.00 & 0.19 & 0.21 & 0.24 & 0.20 & 0.22 & 0.26 \\
Process & 4.19 & 4.74 & 5.28 & 1.00 & 1.00 & 1.00 & 1.00 & 1.16 & 1.32 \\
Output & 3.90 & 4.46 & 5.00 & 0.76 & 0.86 & 1.00 & 1.00 & 1.00 & 1.00 \\
\hline
\end{tabular}

Table 5

Normalized Matrix and weight of factor production to goal EG

\begin{tabular}{lccccc}
\hline & Input & Process & Output & Weight & Rank \\
\hline Input & 0.10 & 0.10 & 0.09 & 0.10 & 3 \\
Process & 0.46 & 0.48 & 0.49 & 0.48 & 1 \\
Output & 0.44 & 0.42 & 0.42 & 0.43 & 2 \\
\hline
\end{tabular}

Table 6

Aggregated fuzzy comparison matrix of factor production to goal ECW

\begin{tabular}{|c|c|c|c|c|c|c|c|c|c|}
\hline & \multicolumn{3}{|c|}{ Input } & \multicolumn{3}{|c|}{ Process } & \multicolumn{3}{|c|}{ Output } \\
\hline Input & (1.00, & 1.00 & $1.00)$ & (0.83, & 1.03, & 1.24) & (0.16, & 0.19 , & $0.24)$ \\
\hline Process & (0.81, & 0.97, & $1.20)$ & (1.00, & 1.00 , & $1.00)$ & (0.34, & 0.40 & $0.50)$ \\
\hline Output & (4.10, & 5.16 & $6.21)$ & $(2.00$, & 2.47, & 2.94) & (1.00, & 1.00 & $1.00)$ \\
\hline
\end{tabular}

Table 7

Normalized Matrix and weight of factor production to goal ECW

\begin{tabular}{lccccc}
\hline & Input & Process & Output & Weight & Rank \\
\hline Input & 0.14 & 0.23 & 0.12 & 0.16 & 3 \\
Process & 0.14 & 0.22 & 0.26 & 0.21 & 2 \\
Output & 0.72 & 0.55 & 0.62 & 0.65 & 1 \\
\hline
\end{tabular}

\section{Table 8}

Aggregated fuzzy comparison matrix of factor production to goal OJO

\begin{tabular}{|c|c|c|c|c|c|c|c|c|c|}
\hline & \multicolumn{3}{|c|}{ Input } & \multicolumn{3}{|c|}{ Process } & \multicolumn{3}{|c|}{ Output } \\
\hline Input & (1.00, & 1.00 , & 1.00) & $(0.25$, & 0.29 , & $0.34)$ & $(0.13$, & 0.15 , & $0.18)$ \\
\hline Process & (2.93, & 3.44, & 4.00) & (1.00, & 1.00, & $1.00)$ & $(0.26$, & 0.31 , & $0.37)$ \\
\hline Output & (5.53, & 6.54 , & 7.55) & $(2.70$, & 3.21 , & $3.78)$ & (1.00, & 1.00, & 1.00) \\
\hline
\end{tabular}

Table 9

Normalized Matrix and weight of factor production to goal OJO

\begin{tabular}{lccccc}
\hline & Input & Process & Output & Weight & Rank \\
\hline Input & 0.09 & 0.06 & 0.11 & 0.09 & 3 \\
Process & 0.31 & 0.22 & 0.21 & 0.25 & 2 \\
Output & 0.60 & 0.71 & 0.68 & 0.68 & 1 \\
\hline
\end{tabular}


Table 10

Aggregated fuzzy comparison matrix of factor production to goal ICA

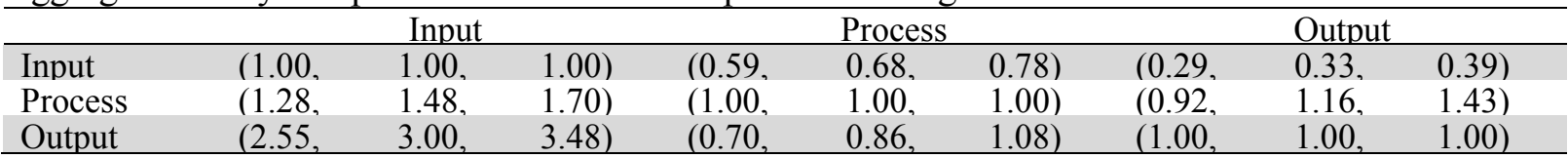

Table 11

Normalized Matrix and weight of factor production to goal ICA

\begin{tabular}{lccccc}
\hline & Input & Process & Output & Weight & Rank \\
\hline Input & 0.18 & 0.27 & 0.13 & 0.20 & 3 \\
Process & 0.27 & 0.39 & 0.47 & 0.38 & 2 \\
Output & 0.55 & 0.34 & 0.40 & 0.44 & 1 \\
\hline
\end{tabular}

From Tables 12-17, we can observe the connection between the factor of production and the criteria. Criteria in this study represented by four factors gainst each production factors. As the results show criteria for input were $\mathrm{C}>\mathrm{FI}>\mathrm{RW}>\mathrm{L}$ (Table 14), whereas criteria for process were $\mathrm{T}>\mathrm{M}>\mathrm{E}>\mathrm{SC}$ (Table 16). Finally, criteria for output were $M>P>L I>E A$ (Table 18).

Table 12

Aggregated fuzzy comparison matrix of criteria (Input)

\begin{tabular}{ccccccccccccc}
\hline & & $\mathrm{L}$ & \multicolumn{3}{c}{ RW } & \multicolumn{3}{c}{$\mathrm{C}$} & \multicolumn{3}{c}{ FI } \\
\hline $\mathrm{L}$ & 1 & 1 & 1 & 0.58 & 0.72 & 0.89 & 0.25 & 0.31 & 0.39 & 0.32 & 0.38 & 0.46 \\
$\mathrm{RW}$ & 1.12 & 1.39 & 1.73 & 1 & 1 & 1 & 0.26 & 0.32 & 0.4 & 0.55 & 0.66 & 0.8 \\
$\mathrm{C}$ & 2.57 & 3.2 & 3.96 & 2.49 & 3.11 & 3.87 & 1 & 1 & 1 & 2.57 & 3.09 & 3.65 \\
$\mathrm{FI}$ & 2.17 & 2.63 & 3.1 & 1.25 & 1.52 & 1.83 & 0.27 & 0.32 & 0.39 & 1 & 1 & 1 \\
\hline
\end{tabular}

Table 13

Normalized Matrix and weight of criteria (Input)

\begin{tabular}{ccccccc}
\hline & L & RW & C & FI & Weight & Rank \\
\hline L & 0.12 & 0.11 & 0.16 & 0.07 & 0.12 & 4 \\
RW & 0.17 & 0.16 & 0.17 & 0.13 & 0.16 & 3 \\
C & 0.39 & 0.49 & 0.51 & 0.60 & 0.52 & 1 \\
FI & 0.32 & 0.24 & 0.17 & 0.19 & 0.23 & 2 \\
\hline
\end{tabular}

Table 14

Aggregated fuzzy comparison matrix of criteria (Process)

\begin{tabular}{ccccccccccccc}
\hline & \multicolumn{3}{c}{$\mathrm{L}$} & \multicolumn{3}{c}{ RW } & & & $\mathrm{C}$ & \multicolumn{3}{c}{ FI } \\
\hline $\mathrm{L}$ & 1 & 1 & 1 & 0.58 & 0.72 & 0.89 & 0.25 & 0.31 & 0.39 & 0.32 & 0.38 & 0.46 \\
$\mathrm{RW}$ & 1.12 & 1.39 & 1.73 & 1 & 1 & 1 & 0.26 & 0.32 & 0.4 & 0.55 & 0.66 & 0.8 \\
$\mathrm{C}$ & 2.57 & 3.2 & 3.96 & 2.49 & 3.11 & 3.87 & 1 & 1 & 1 & 2.57 & 3.09 & 3.65 \\
$\mathrm{FI}$ & 2.17 & 2.63 & 3.1 & 1.25 & 1.52 & 1.83 & 0.27 & 0.32 & 0.39 & 1 & 1 & 1 \\
\hline
\end{tabular}

Table 15

Normalized Matrix and weight of criteria (Process)

\begin{tabular}{ccccccc}
\hline & $\mathrm{T}$ & $\mathrm{SC}$ & $\mathrm{M}$ & $\mathrm{E}$ & Weight & Rank \\
\hline $\mathrm{T}$ & 0.68 & 0.53 & 0.72 & 0.73 & 0.69 & 1 \\
$\mathrm{SC}$ & 0.10 & 0.08 & 0.05 & 0.04 & 0.07 & 4 \\
$\mathrm{M}$ & 0.11 & 0.19 & 0.12 & 0.11 & 0.14 & 2 \\
$\mathrm{E}$ & 0.10 & 0.19 & 0.12 & 0.11 & 0.13 & 3 \\
\hline
\end{tabular}

\section{Table 16}

Aggregated fuzzy comparison matrix of criteria (Output)

\begin{tabular}{lccccccccccc}
\hline & & $\mathrm{L}$ & & & RW & & & $\mathrm{C}$ & & FI \\
\hline L & 1.00 & 1.00 & 1.00 & 0.58 & 0.72 & 0.25 & 0.31 & 0.39 & 0.32 & 0.38 & 0.46 \\
RW & 1.12 & 1.39 & 1.73 & 1.00 & 1.00 & 0.26 & 0.32 & 0.40 & 0.55 & 0.66 & 0.80 \\
C & 2.57 & 3.20 & 3.96 & 2.49 & 3.11 & 1.00 & 1.00 & 1.00 & 2.57 & 3.09 & 3.65 \\
FI & 2.17 & 2.63 & 3.10 & 1.25 & 1.52 & 1.83 & 0.27 & 0.32 & 1.00 & 1.00 & 1.00 \\
\hline
\end{tabular}


Table 17

Normalized matrix and weight of criteria (Output)

\begin{tabular}{ccccccc}
\hline & $\mathrm{M}$ & $\mathrm{P}$ & EI & LA & Weight & Rank \\
\hline $\mathrm{M}$ & 0.36 & 0.43 & 0.36 & 0.24 & 0.36 & 1 \\
$\mathrm{P}$ & 0.21 & 0.25 & 0.35 & 0.21 & 0.26 & 2 \\
EI & 0.21 & 0.15 & 0.21 & 0.41 & 0.25 & 3 \\
LA & 0.21 & 0.16 & 0.07 & 0.14 & 0.15 & 4 \\
\hline
\end{tabular}

The final weight and rank can be seen on Table 18, where final weight for production factors were Output $>$ Process $>$ Input. This shows the empirical indication on the importance on the emphasize for local government and fishers and aquaculture farmer in the region to pay more attention on the final product. Marine and fisheries resources are renewable resources but it takes more than a century to renew but they have high biodiversity and resources, Southeast Maluku has to focus on increase the quality of the end product. By doing so, the goal on enhancing economic welfare of coastal community can be achieved.

Table 18

Final ranking of top fisheries sub-sector for each sub-districts in Southeast Maluku

\begin{tabular}{|c|c|c|c|c|c|c|c|c|}
\hline Goal & Weight & $\begin{array}{l}\text { Production } \\
\text { Factor }\end{array}$ & Weight & $\begin{array}{l}\text { Finalized } \\
\text { Weight }\end{array}$ & Criteria & Weight & $\begin{array}{l}\text { Finalized } \\
\text { Weight }\end{array}$ & $\begin{array}{l}\text { Global } \\
\text { Rank }\end{array}$ \\
\hline \multirow{3}{*}{ EG } & \multirow{3}{*}{0.05} & \multirow{4}{*}{ Input } & 0.10 & \multirow{4}{*}{0.14} & $\mathrm{~L}$ & 0.12 & 0.02 & 12 \\
\hline & & & 0.16 & & RW & 0.16 & 0.02 & 10 \\
\hline & & & 0.09 & & $\mathrm{C}$ & 0.52 & 0.07 & 6 \\
\hline \multirow{4}{*}{ ECW } & & & 0.20 & & FI & 0.23 & 0.03 & 9 \\
\hline & 0.51 & \multirow{5}{*}{ Process } & 0.48 & \multirow{4}{*}{0.26} & $\mathrm{~T}$ & 0.69 & 0.18 & 2 \\
\hline & & & 0.21 & & $\mathrm{SC}$ & 0.07 & 0.02 & 11 \\
\hline & \multirow{3}{*}{0.37} & & 0.25 & & $\mathrm{M}$ & 0.14 & 0.04 & 7 \\
\hline \multirow[t]{2}{*}{ OJO } & & & 0.38 & & $\mathrm{E}$ & 0.13 & 0.03 & 8 \\
\hline & & & 0.43 & \multirow{4}{*}{0.64} & M & 0.36 & 0.23 & 1 \\
\hline \multirow{3}{*}{ ICA } & \multirow{3}{*}{0.09} & & 0.65 & & $\mathrm{P}$ & 0.26 & 0.17 & 3 \\
\hline & & Output & 0.68 & & EI & 0.25 & 0.16 & 4 \\
\hline & & & 0.44 & & LA & 0.15 & 0.09 & 5 \\
\hline
\end{tabular}

The final weights on the criteria are shown in Table 19 which are market, technology and price. These three criteria are the current problem to be dealing with in the region. The cost delivery and distribution of marine and fisheries commodity in the region are too high because of the difficulties in the location, which make it hard to compete with others, and to access the market. Ankamah-Yeboah et al. (2017) show, maket and price volatile on fishes commodity related to seasonal, also Oglend (2013) pointed out the volatility of fisheries and marine price which were related to other product namely meat and oils which are also trigger of problem to maintain the continuity which can lead to failure to maintain the current market and compete on price. Although the use of technology can increase income as confirmed by Abraham (2006); Jensen (2007) indicated the use of technology in form of mobile phone can increase the efficiency and income of fishermen.

Therefore, in order to deal with all issues, the region has to be focus on their issues based on the criteria given shown in Tables 22 to 23 and illustrated on Fig. 3, where the highest CCi for each sub-district for fisheries sub-sectors were for Kei kecil sub-districts Fishing $>$ Ecotoursim $>$ Mariculture $>$ Marine processing product (Table 22). As for remaining sub-districts were Kei Kecil Barat sub-district were Fishing $>$ Marine Culture $>$ Marine Ecotourism $>$ Marine Processing Product; Hoat Sorbay sub-district were Marine culture $>$ Marine Ecotourism $>$ Fishing $>$ Marin Processing Product; Manyeuw subdistrict were Marine Ecotourism $>$ Fishing $>$ Marine Culture $>$ Marine Processing Product; Kei Kecil Timur sub-district were Marine Culture $>$ Fishing $>$ Marine Ecotourism > Marine Processing Product; Kei Kecil Timur Selatan sub-district were Marine Ecotourism $>$ Marine Culture $>$ Fishing $>$ Marine Processing Product; Kei Besar sub-district were Fishing $>$ Marine Culture $>$ Marine Ecotourism $>$ Marine Processing Product; Kei Besar Selatan sub-district were Fishing $>$ Marine Culture $>$ Marine Ecotourism > Marine Processing Product; Kei Besar Selatan Barat sub-district were Marine Culture > 
Fishing $>$ Marine Ecotourism $>$ Marine Processing Product; Kei Besar Utara Barat sub-district were Fishing $>$ Marine Culture $>$ Marine Ecotourism $>$ Marine Processing Product; Kei Besar Utara Timur sub-district were Fishing $>$ Marine Culture $>$ Marine Ecotourism $>$ Marine Processing Product (Table 22).

Table 19

Normalized matrix for Kei Kecil Sub-District

\begin{tabular}{|c|c|c|c|c|c|c|c|c|c|c|c|c|}
\hline & \multicolumn{3}{|c|}{$\mathrm{X} 1$} & \multicolumn{3}{|c|}{$\mathrm{X} 2$} & \multicolumn{3}{|c|}{ X3 } & \multicolumn{3}{|c|}{$\mathrm{X} 4$} \\
\hline A1 & 0.57 & 0.80 & 1.00 & 0.59 & 0.80 & 1.00 & 0.60 & 0.81 & 0.98 & 0.59 & 0.81 & 1.00 \\
\hline A2 & 0.52 & 0.75 & 0.98 & 0.50 & 0.72 & 0.93 & 0.65 & 0.85 & 1.00 & 0.46 & 0.65 & 0.81 \\
\hline A3 & 0.39 & 0.61 & 0.84 & 0.59 & 0.80 & 1.00 & 0.35 & 0.56 & 0.77 & 0.28 & 0.46 & 0.65 \\
\hline \multirow[t]{2}{*}{ A4 } & 0.34 & 0.57 & 0.80 & 0.59 & 0.80 & 1.00 & 0.40 & 0.60 & 0.81 & 0.43 & 0.61 & 0.80 \\
\hline & \multicolumn{3}{|c|}{$\mathrm{X} 5$} & \multicolumn{3}{|c|}{$\mathrm{X} 6$} & \multicolumn{3}{|c|}{$\mathrm{X} 7$} & \multicolumn{3}{|c|}{$\mathrm{X} 8$} \\
\hline A1 & 0.57 & 0.80 & 1.00 & 0.55 & 0.76 & 0.94 & 0.55 & 0.79 & 1.00 & 0.48 & 0.69 & 0.88 \\
\hline A2 & 0.48 & 0.70 & 0.93 & 0.55 & 0.76 & 0.94 & 0.31 & 0.55 & 0.79 & 0.48 & 0.69 & 0.88 \\
\hline A3 & 0.34 & 0.57 & 0.80 & 0.47 & 0.67 & 0.88 & 0.17 & 0.40 & 0.64 & 0.56 & 0.77 & 0.96 \\
\hline \multirow[t]{2}{*}{ A4 } & 0.39 & 0.61 & 0.84 & 0.67 & 0.88 & 1.00 & 0.24 & 0.45 & 0.69 & 0.65 & 0.85 & 1.00 \\
\hline & \multicolumn{3}{|c|}{ X9 } & \multicolumn{3}{|c|}{ X10 } & \multicolumn{3}{|c|}{ X11 } & \multicolumn{3}{|c|}{$\mathrm{X} 12$} \\
\hline A1 & 0.58 & 0.78 & 0.94 & 0.51 & 0.73 & 0.96 & 0.52 & 0.73 & 0.92 & 0.37 & 0.59 & 0.80 \\
\hline A2 & 0.38 & 0.58 & 0.78 & 0.42 & 0.64 & 0.87 & 0.65 & 0.85 & 1.00 & 0.59 & 0.80 & 1.00 \\
\hline A3 & 0.30 & 0.50 & 0.70 & 0.33 & 0.56 & 0.78 & 0.40 & 0.60 & 0.81 & 0.37 & 0.59 & 0.80 \\
\hline A4 & 0.70 & 0.90 & 1.00 & 0.56 & 0.78 & 1.00 & 0.52 & 0.73 & 0.92 & 0.37 & 0.59 & 0.80 \\
\hline
\end{tabular}

Table 20

Weighted normalized fuzzy decision matrix for Kei Kecil Sub-District

\begin{tabular}{|c|c|c|c|c|c|c|c|c|c|c|c|c|}
\hline & \multicolumn{3}{|c|}{$\mathrm{X} 1$} & \multicolumn{3}{|c|}{$\mathrm{X} 2$} & \multicolumn{3}{|c|}{ X3 } & \multicolumn{3}{|c|}{$\mathrm{X} 4$} \\
\hline A1 & 0.01 & 0.01 & 0.02 & 0.01 & 0.02 & 0.02 & 0.04 & 0.06 & 0.07 & 0.02 & 0.03 & 0.03 \\
\hline A2 & 0.01 & 0.01 & 0.02 & 0.01 & 0.02 & 0.02 & 0.05 & 0.06 & 0.07 & 0.01 & 0.02 & 0.03 \\
\hline A3 & 0.01 & 0.01 & 0.01 & 0.01 & 0.02 & 0.02 & 0.03 & 0.04 & 0.06 & 0.01 & 0.01 & 0.02 \\
\hline \multirow[t]{2}{*}{ A4 } & 0.01 & 0.01 & 0.01 & 0.01 & 0.02 & 0.02 & 0.03 & 0.04 & 0.06 & 0.01 & 0.02 & 0.03 \\
\hline & \multicolumn{3}{|c|}{$\mathrm{X5}$} & \multicolumn{3}{|c|}{ X6 } & \multicolumn{3}{|c|}{$\mathrm{X7}$} & \multicolumn{3}{|c|}{ X8 } \\
\hline A1 & 0.1 & 0.14 & 0.18 & 0.01 & 0.01 & 0.02 & 0.02 & 0.03 & 0.04 & 0.02 & 0.02 & 0.03 \\
\hline A2 & 0.08 & 0.12 & 0.16 & 0.01 & 0.01 & 0.02 & 0.01 & 0.02 & 0.03 & 0.02 & 0.02 & 0.03 \\
\hline A3 & 0.06 & 0.1 & 0.14 & 0.01 & 0.01 & 0.02 & 0.01 & 0.01 & 0.02 & 0.02 & 0.03 & 0.03 \\
\hline \multirow[t]{2}{*}{ A4 } & 0.07 & 0.11 & 0.15 & 0.01 & 0.02 & 0.02 & 0.01 & 0.02 & 0.02 & 0.02 & 0.03 & 0.03 \\
\hline & \multicolumn{3}{|c|}{ X9 } & \multicolumn{3}{|c|}{$\mathrm{X} 10$} & \multicolumn{3}{|c|}{ X11 } & \multicolumn{3}{|c|}{ X12 } \\
\hline A1 & 0.14 & 0.18 & 0.22 & 0.09 & 0.13 & 0.16 & 0.08 & 0.12 & 0.15 & 0.04 & 0.06 & 0.08 \\
\hline A2 & 0.09 & 0.14 & 0.18 & 0.07 & 0.11 & 0.15 & 0.1 & 0.14 & 0.16 & 0.06 & 0.08 & 0.09 \\
\hline A3 & 0.07 & 0.12 & 0.16 & 0.06 & 0.09 & 0.13 & 0.06 & 0.1 & 0.13 & 0.04 & 0.06 & 0.08 \\
\hline A4 & 0.16 & 0.21 & 0.23 & 0.09 & 0.13 & 0.17 & 0.08 & 0.12 & 0.15 & 0.04 & 0.06 & 0.08 \\
\hline
\end{tabular}

Table 21

Distance, Closeness coefficient (CCi) and final ranking of the fisheries sub-sector of Kei Kecil SubDistrict

\begin{tabular}{lrccc}
\hline Fisheries Sub-Sector & D + & D- & CCi & Ranking \\
\hline Fishing & 0.325559 & 0.805079 & 0.712057 & 1 \\
Marine Culture & 0.369858 & 0.758027 & 0.672078 & 3 \\
Marine Processing & 0.500481 & 0.621779 & 0.554042 & 4 \\
Marine Ecotourism & 0.349186 & 0.778908 & 0.690464 & 2 \\
\hline
\end{tabular}

Based on Tables 2-18, with the same processing on Fuzzy TOPSIS as Tables 19-21, we calculated the top sub-sector for the remaining $10^{\text {th }}$ sub-districts in Southeast Maluku District, and the results can be seen in Table 22. 
Table 22

Final ranking of fisheries sub-sector for remaining sub-districts

\begin{tabular}{|c|c|c|c|c|}
\hline \multicolumn{5}{|c|}{ Kei Kecil Barat Sub-District } \\
\hline Fisheries Sub-Sector & $\mathrm{D}+$ & D- & $\mathrm{CCi}$ & Ranking \\
\hline Fishing & 0.316 & 0.827 & 0.723 & 1 \\
\hline Marine Culture & 0.358 & 0.769 & 0.682 & 2 \\
\hline Marine Processing & 0.536 & 0.587 & 0.523 & 4 \\
\hline Marine Ecotourism & 0.426 & 0.704 & 0.623 & 3 \\
\hline \multicolumn{5}{|c|}{ Hoat Sorbay Sub-District } \\
\hline Fisheries Sub-Sector & $\mathrm{D}+$ & D- & $\mathrm{CCi}$ & Ranking \\
\hline Fishing & 0.368 & 0.762 & 0.674 & 3 \\
\hline Marine Culture & 0.265 & 0.872 & 0.767 & 1 \\
\hline Marine Processing & 0.579 & 0.544 & 0.485 & 4 \\
\hline Marine Ecotourism & 0.307 & 0.827 & 0.729 & 2 \\
\hline \multicolumn{5}{|c|}{ Manyeuw Sub-District } \\
\hline Fisheries Sub-Sector & $\mathrm{D}+$ & D- & $\mathrm{CCi}$ & Ranking \\
\hline Fishing & 0.323 & 0.812 & 0.716 & 2 \\
\hline Marine Culture & 0.354 & 0.778 & 0.687 & 3 \\
\hline Marine Processing & 0.585 & 0.539 & 0.479 & 4 \\
\hline Marine Ecotourism & 0.282 & 0.856 & 0.752 & 1 \\
\hline \multicolumn{5}{|c|}{ Kei Kecil Timur Sub-District } \\
\hline Fisheries Sub-Sector & $\mathrm{D}+$ & D- & $\mathrm{CCi}$ & Ranking \\
\hline Fishing & 0.428 & 0.731 & 0.631 & 2 \\
\hline Marine Culture & 0.372 & 0.795 & 0.681 & 1 \\
\hline Marine Processing & 0.538 & 0.614 & 0.533 & 4 \\
\hline Marine Ecotourism & 0.527 & 0.623 & 0.542 & 3 \\
\hline \multicolumn{5}{|c|}{ Kei Kecil Timur Selatan Sub-District } \\
\hline Fisheries Sub-Sector & $\mathrm{D}+$ & D- & $\mathrm{CCi}$ & Ranking \\
\hline Fishing & 0.428 & 0.719 & 0.627 & 3 \\
\hline Marine Culture & 0.385 & 0.768 & 0.666 & 2 \\
\hline Marine Processing & 0.597 & 0.546 & 0.478 & 4 \\
\hline Marine Ecotourism & 0.349 & 0.806 & 0.698 & 1 \\
\hline \multicolumn{5}{|c|}{ Kei Besar Sub-District } \\
\hline Fisheries Sub-Sector & $\mathrm{D}+$ & $\mathrm{D}-$ & $\mathrm{CCi}$ & Ranking \\
\hline Fishing & 0.343 & 0.810 & 0.703 & 1 \\
\hline Marine Culture & 0.344 & 0.808 & 0.702 & 2 \\
\hline Marine Processing & 0.583 & 0.556 & 0.488 & 3 \\
\hline Marine Ecotourism & 0.469 & 0.674 & 0.590 & 4 \\
\hline \multicolumn{5}{|c|}{ Kei Besar Selatan Sub-District } \\
\hline Fisheries Sub-Sector & $\mathrm{D}+$ & D- & $\mathrm{CCi}$ & Ranking \\
\hline Fishing & 0.334 & 0.827 & 0.712 & 1 \\
\hline Marine Culture & 0.390 & 0.773 & 0.665 & 2 \\
\hline Marine Processing & 0.589 & 0.558 & 0.486 & 4 \\
\hline Marine Ecotourism & 0.535 & 0.617 & 0.535 & 3 \\
\hline \multicolumn{5}{|c|}{ Kei Besar Selatan Barat Sub-District } \\
\hline Fisheries Sub-Sector & $\mathrm{D}+$ & D- & $\mathrm{CCi}$ & Ranking \\
\hline Fishing & 0.349 & 0.803 & 0.697 & 2 \\
\hline Marine Culture & 0.341 & 0.811 & 0.704 & 1 \\
\hline Marine Processing & 0.636 & 0.501 & 0.441 & 4 \\
\hline Marine Ecotourism & 0.563 & 0.575 & 0.505 & 3 \\
\hline \multicolumn{5}{|c|}{ Kei Besar Utara Barat Sub-District } \\
\hline Fisheries Sub-Sector & $\mathrm{D}+$ & D- & $\mathrm{CCi}$ & Ranking \\
\hline Fishing & 0.354 & 0.812 & 0.696 & 1 \\
\hline Marine Culture & 0.399 & 0.763 & 0.657 & 2 \\
\hline Marine Processing & 0.628 & 0.521 & 0.453 & 4 \\
\hline Marine Ecotourism & 0.463 & 0.694 & 0.600 & 3 \\
\hline \multicolumn{5}{|c|}{ Kei Besar Utara Timur Sub-District } \\
\hline Fisheries Sub-Sector & $\mathrm{D}+$ & D- & $\mathrm{CCi}$ & Ranking \\
\hline Fishing & 0.302 & 0.847 & 0.737 & 1 \\
\hline Marine Culture & 0.378 & 0.765 & 0.669 & 2 \\
\hline Marine Processing & 0.575 & 0.557 & 0.492 & 4 \\
\hline Marine Ecotourism & 0.545 & 0.587 & 0.519 & 3 \\
\hline
\end{tabular}




\section{Sensitivity analysis}

The sensitivity analysis has been performed to examine the influence of the preferences given by the decision makers to select the top fisheries sub-sectors on each sub-district in the region based on weight of criteria on Table 19 to measure the change on CCi value. On this study we have used three scenarios, first criterion is associated with production factor input where half of the weight out of all four criteria are given 0.125 and the rest equally spread with 0.0625 . Second scenario, criterion of factor production process, we spread half of the value for four criteria with 0.125 and the rest is given 0.0625 each, for third scenario the same as the previous scenario, this time criteria of production factors output each were given 0.125 and the rest received 0.0625 .

As seen on Table 23 and Fig. 4 there is no significant change on ranking fisheries sub-sectors of each sub-district excluding Kei Besar Sub-District where for scenario two there was a tied between fishing and marine culture sub-sectors, and Kei Besar Selatan Sub-District where on scenario three we have marine culture $>$ fishing. Therefore, the results of sensitivity analysis experiment represented that the result was not relatively sensitive to 9 sub-districts and relatively sensitive to 2 sub-districts.

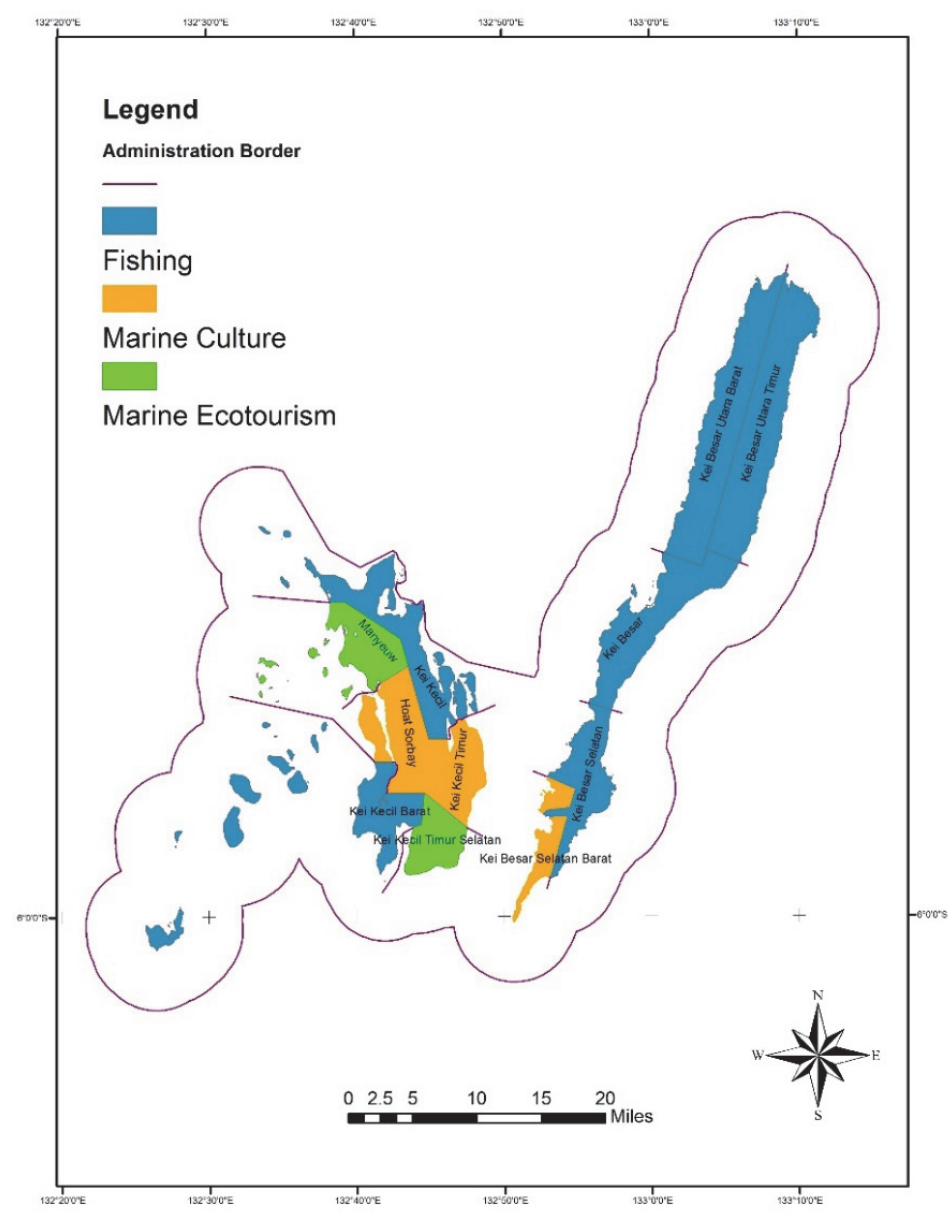

Fig. 4. Mapping Top Fisheries Sub-sectors in Southeast Maluku District

\section{Conclusion}

Integratation of Fuzzy AHP and Fuzzy TOPSIS has been proven to be a useful and powerful tool to to obtain a solution based on a very complicated variables. As shown on the result, enhance economic welfare of coastal community was the main goal of the selecting the top sub-sector in fisheries in Southeast Maluku District, where increasing the quality and maintaining the continuity of output were the main concern, whereas technology, market and price were three criteria that can contribute to 
increase the quality and quantity of the product. As the final results show the sub-districts that had prospect and potential in fishing are Kei Kecil sub-district, Kei Kecil Barat sub-district, Kei Besar subdistrict, Kei Besar Selatan sub-district, Kei Besar Utara Barat sub-district and Kei Besar Utara Timur sub-district. For Marine culture are Hoat Sorbay sub-district, Kei Kecil Timur sub-district, Kei Besar Selatan Barat sub-district. Marine Ecotourism are Manyeuw sub-district and Kei Kecil Timur Selatan sub-district.

Table 23

Sensitivity analysis

\begin{tabular}{|c|c|c|c|}
\hline \multicolumn{4}{|c|}{ Kei Kecil Sub-District } \\
\hline Fisheries Sub-Sector & Scenario 1 & Scenario 2 & Scenario 3 \\
\hline Fishing & 0.719 & 0.712 & 0.703 \\
\hline Marine Culture & 0.678 & 0.668 & 0.678 \\
\hline Marine Processing & 0.573 & 0.577 & 0.568 \\
\hline Marine Ecotourism & 0.649 & 0.663 & 0.674 \\
\hline \multicolumn{4}{|c|}{ Kei Kecil Barat Sub-District } \\
\hline Fisheries Sub-Sector & Scenario 1 & Scenario 2 & Scenario 3 \\
\hline Fishing & 0.729 & 0.729 & 0.722 \\
\hline Marine Culture & 0.697 & 0.690 & 0.710 \\
\hline Marine Processing & 0.558 & 0.554 & 0.557 \\
\hline Marine Ecotourism & 0.633 & 0.640 & 0.635 \\
\hline \multicolumn{4}{|c|}{ Kei Kecil Timur Sub-District } \\
\hline Fisheries Sub-Sector & Scenario 1 & Scenario 2 & Scenario 3 \\
\hline Fishing & 0.618 & 0.616 & 0.620 \\
\hline Marine Culture & 0.670 & 0.673 & 0.682 \\
\hline Marine Processing & 0.567 & 0.576 & 0.551 \\
\hline Marine Ecotourism & 0.585 & 0.587 & 0.567 \\
\hline \multicolumn{4}{|c|}{ Kei Kecil Timur Selatan Sub-District } \\
\hline Fisheries Sub-Sector & Scenario 1 & Scenario 2 & Scenario 3 \\
\hline Fishing & 0.637 & 0.641 & 0.633 \\
\hline Marine Culture & 0.656 & 0.651 & 0.665 \\
\hline Marine Processing & 0.497 & 0.505 & 0.491 \\
\hline Marine Ecotourism & 0.681 & 0.691 & 0.689 \\
\hline \multicolumn{4}{|c|}{ Manveuw Sub-District } \\
\hline Fisheries Sub-Sector & Scenario 1 & Scenario 2 & Scenario 3 \\
\hline Fishing & 0.701 & 0.707 & 0.708 \\
\hline Marine Culture & 0.690 & 0.681 & 0.693 \\
\hline Marine Processing & 0.517 & 0.504 & 0.495 \\
\hline Marine Ecotourism & 0.763 & 0.762 & 0.755 \\
\hline \multicolumn{4}{|c|}{ Hoat Sorbav Sub-District } \\
\hline Fisheries Sub-Sector & Scenario 1 & Scenario 2 & Scenario 3 \\
\hline Fishing & 0.659 & 0.662 & 0.667 \\
\hline Marine Culture & 0.761 & 0.765 & 0.763 \\
\hline Marine Processing & 0.500 & 0.488 & 0.494 \\
\hline Marine Ecotourism & 0.710 & 0.719 & 0.726 \\
\hline \multicolumn{4}{|c|}{ Kei Besar Sub-District } \\
\hline Fisheries Sub-Sector & Scenario 1 & Scenario 2 & Scenario 3 \\
\hline Fishing & 0.696 & 0.702 & 0.697 \\
\hline Marine Culture & 0.696 & 0.702 & 0.705 \\
\hline Marine Processing & 0.473 & 0.484 & 0.497 \\
\hline Marine Ecotourism & 0.537 & 0.560 & 0.577 \\
\hline \multicolumn{4}{|c|}{ Kei Besar Selatan Sub-District } \\
\hline Fisheries Sub-Sector & Scenario 1 & Scenario 2 & Scenario 3 \\
\hline Fishing & 0.712 & 0.717 & 0.712 \\
\hline Marine Culture & 0.661 & 0.657 & 0.668 \\
\hline Marine Processing & 0.505 & 0.506 & 0.490 \\
\hline Marine Ecotourism & 0.528 & 0.547 & 0.525 \\
\hline \multicolumn{4}{|c|}{ Kei Besar Selatan Barat Sub-District } \\
\hline Fisheries Sub-Sector & Scenario 1 & Scenario 2 & Scenario 3 \\
\hline Fishing & 0.706 & 0.712 & 0.705 \\
\hline Marine Culture & 0.705 & 0.707 & 0.709 \\
\hline Marine Processing & 0.448 & 0.461 & 0.448 \\
\hline Marine Ecotourism & 0.523 & 0.516 & 0.503 \\
\hline \multicolumn{4}{|c|}{ Kei Besar Utara Barat Sub-District } \\
\hline Fisheries Sub-Sector & Scenario 1 & Scenario 2 & Scenario 3 \\
\hline Fishing & 0.706 & 0.707 & 0.699 \\
\hline Marine Culture & 0.648 & 0.655 & 0.652 \\
\hline Marine Processing & 0.464 & 0.467 & 0.458 \\
\hline Marine Ecotourism & 0.595 & 0.610 & 0.611 \\
\hline \multicolumn{4}{|c|}{ Kei Besar Utara Timur Sub-District } \\
\hline Fisheries Sub-Sector & Scenario 1 & Scenario 2 & Scenario 3 \\
\hline Fishing & 0.725 & 0.731 & 0.732 \\
\hline Marine Culture & 0.631 & 0.633 & 0.654 \\
\hline Marine Processing & 0.514 & 0.508 & 0.495 \\
\hline Marine Ecotourism & 0.570 & 0.565 & 0.542 \\
\hline
\end{tabular}

The results of this survey are usefule for most of current marine and fisheries commodity in the region to manage the raw materials such as fishes, seaweed, sea cucumber, pearl etc, thus for better income 
generated and preserve the resources every stakeholder in the region has to start to be more focus to increase the quality and prices of the commodity by selling and exporting intermediate and pre-process commodities, for example instead the raw seaweed, the carrageenan can be an option, and, instead of raw fishes, the local government can push for the production of fish powder. In general, shift from raw output to intermediate-input to other output can increase both quality and price which can also increase the revenue of coastal community in the region. Despite the lack of labor capability and technology requirements, the abundant of resources can provide an advantage. Therefore, local government has to craft a better developing plan to address the issue by providin SMEs based processing commodity accordingly to the advantage of each sub-district in the region, for instance building fish processing in Kei Besar Utara Selatan sub-district, Kei Besar Utara Barat sub-district and Kei Besar sub-district. By doing so, the added value of fisheries commodity and income of coastal community in those area can increase.

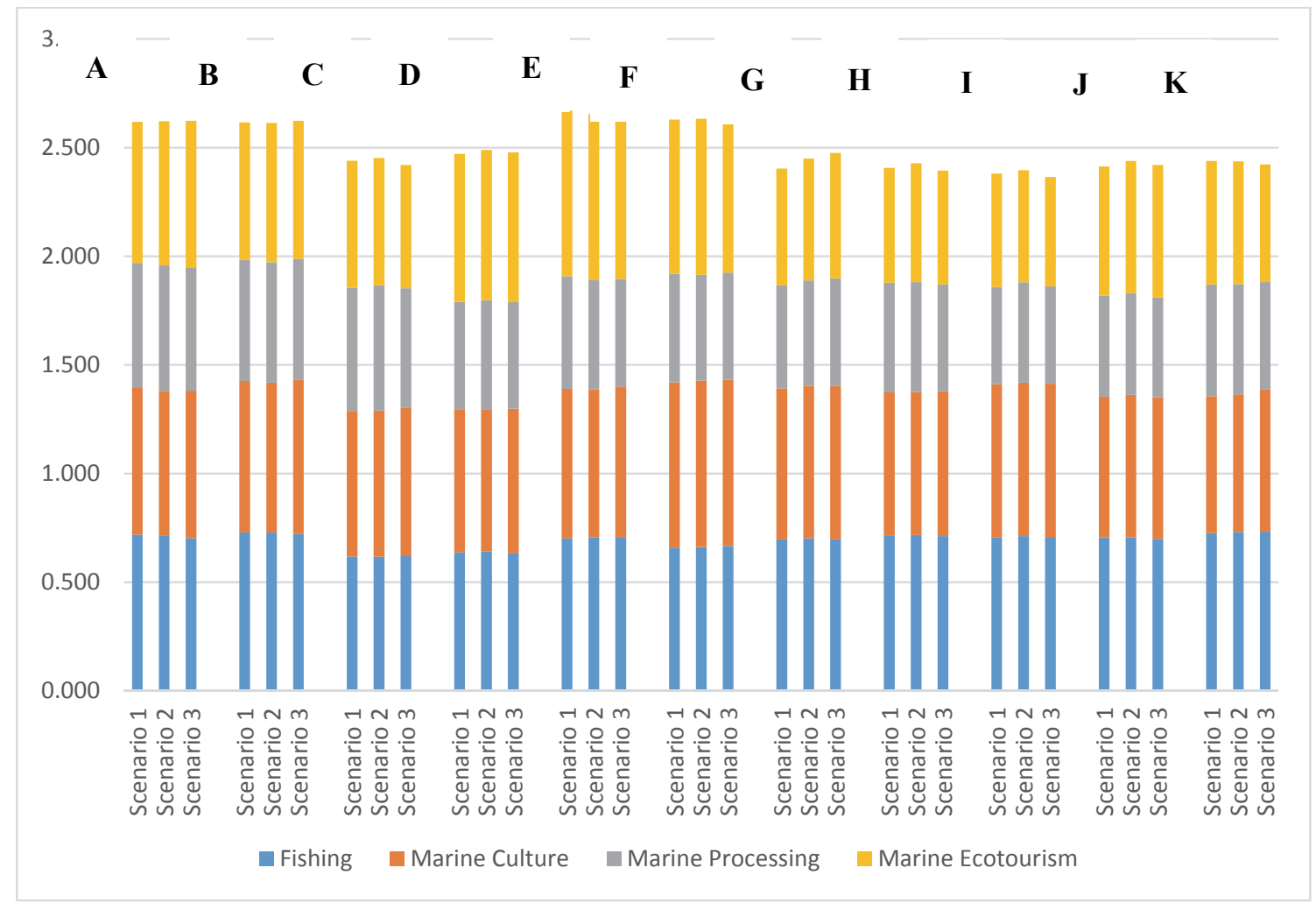

Fig. 4. Sensitivity analysis. A: Kei Kecil Sub-District; B: Kei Kecil Barat Sub-District; C: Kei Kecil Timur Sub-District; D: Kei Kecil Timur Selatan Sub-District; E: Manyeuw Sub-District; F: Hoat Sorbay Sub-District; G: Kei Besar Sub-District; H: Kei Besar Selatan Sub-District; I: Kei Besar Selatan Barat Sub-District; J: Kei Besar Utara Barat Sub-District; K: Kei Besar Utara Timur SubDistrict

\section{Acknowledgement}

The authors thank Directorate of Research and Community Service, Ministry of Research and Technology the Higher Education Republic of Indonesia for funding this research under PDUPT scheme. The result of this study does not represent an official policy of the Southeast Maluku District government and this study was performed solely for educational purposes. 


\section{References}

Abraham, R. (2006, May). Mobile phones and economic development: Evidence from the fishing industry in India. In 2006 International Conference on Information and Communication Technologies and Development (pp. 48-56). IEEE.

Al Mamun, M. A., Howladar, M. F., \& Sohail, M. A. (2019). Assessment of surface water quality using Fuzzy Analytic Hierarchy Process (FAHP): A case study of Piyain River's sand and gravel quarry mining area in Jaflong, Sylhet. Groundwater for Sustainable Development.

Ankamah-Yeboah, I., Nielsen, M., \& Nielsen, R. (2017). Price formation of the salmon aquaculture futures market. Aquaculture Economics \& Management, 21(3), 376-399.

Ayhan, M. B. (2019). Supplier evaluation with hesitant fuzzy analytic hierarchy process in bearing sector and consistency analysis. Journal of Testing and Evaluation, 48(1).

Bappenas (2014). Rencana Pembangunan Jangka Menengah Nasional (RPJMN) 2015-2019. Peraturan Presiden Republik Indonesia Nomor, 2.

Büyüközkan, G., \& Çifçi, G. (2012). A combined fuzzy AHP and fuzzy TOPSIS based strategic analysis of electronic service quality in healthcare industry. Expert Systems with Applications, 39(3), 2341-2354.

Celik, E., \& Akyuz, E. (2018). An interval type-2 fuzzy AHP and TOPSIS methods for decision-making problems in maritime transportation engineering: the case of ship loader. Ocean Engineering, 155, 371-381.

Chang, D. Y. (1996). Applications of the extent analysis method on fuzzy AHP. European Journal of Operational Research, 95, 649-655.

Chou, Y. C., Yen, H. Y., Dang, V. T., \& Sun, C. C. (2019). Assessing the human resource in science and technology for asian countries: Application of fuzzy AHP and fuzzy TOPSIS. Symmetry, 11(2), 251.

Del Sol, P., \& Kogan, J. (2007). Regional competitive advantage based on pioneering economic reforms: The case of Chilean FDI. Journal of International Business Studies, 38(6), 901-927.

Dursun, M., \& Karsak, E. E. (2010). A fuzzy MCDM approach for personnel selection. Expert Systems with applications, 37(6), 4324-4330.

Giamalaki, M., \& Tsoutsos, T. (2019). Sustainable siting of solar power installations in Mediterranean using a GIS/AHP approach. Renewable Energy, 141, 64-75.

Gou, X., Xu, Z., \& Liao, H. (2017). Hesitant fuzzy linguistic entropy and cross-entropy measures and alternative queuing method for multiple criteria decision making. Information Sciences, 388, 225246.

Gumus, A. T. (2009). Evaluation of hazardous waste transportation firms by using a two step fuzzyAHP and TOPSIS methodology. Expert Systems with Applications, 36(2), 4067-4074.

Hamid, S. K., Teniwut, W. A., Teniwut, R. M., Rahantoknam, M. A., Hasyim, C. L., \& Hungan, M. (2017). The Support of MPA (Marine Protected Area) in Coral Triangle Area: Evidence from Kei Islands, Indonesia. In IOP Conference Series: Earth and Environmental Science (Vol. 89, No. 1, p. 012025). IOP Publishing.

Havle, C. A., \& Kılıç, B. (2019). A hybrid approach based on the fuzzy AHP and HFACS framework for identifying and analyzing gross navigation errors during transatlantic flights. Journal of Air Transport Management, 76, 21-30.

Hill, E. W., \& Brennan, J. F. (2000). A methodology for identifying the drivers of industrial clusters: the foundation of regional competitive advantage. Economic Development Quarterly, 14(1), 65-96.

Hsieh, M. C., Wang, E. M. Y., Lee, W. C., Li, L. W., Hsieh, C. Y., Tsai, W., ... \& Liu, T. C. (2018). Application of HFACS, fuzzy TOPSIS, and AHP for identifying important human error factors in emergency departments in Taiwan. International Journal of Industrial Ergonomics, 67, 171-179.

Jensen, R. (2007). The digital provide: Information (technology), market performance, and welfare in the South Indian fisheries sector. The Quarterly Journal of Economics, 122(3), 879-924. 
Kannan, D., Jabbour, A. B. L. D. S., \& Jabbour, C. J. C. (2014). Selecting green suppliers based on GSCM practices: Using fuzzy TOPSIS applied to a Brazilian electronics company. European Journal of Operational Research, 233, 432-447.

Loizou, E., Karelakis, C., Galanopoulos, K., \& Mattas, K. (2019). The role of agriculture as a development tool for a regional economy. Agricultural Systems, 173, 482-490.

Mandic, K., Delibasic, B., Knezevic, S., \& Benkovic, S. (2014). Analysis of the financial parameters of Serbian banks through the application of the fuzzy AHP and TOPSIS methods. Economic Modelling, 43, 30-37.

Oglend, A. (2013). Recent trends in salmon price volatility. Aquaculture Economics \& Management, 17(3), 281-299.

Picaulima, S., Teniwut, W. A., Kahfi, S., Teniwut, R. M., Susanti, I. I. D. A. R., Hungan, M., ... \& Ngabalin, A. M. (2017). Mapping Marine Resources Utilization Based on Seascapes Area: A Study on Gender Comparison. In IOP Conference Series: Earth and Environmental Science (Vol. 89, No. 1, p. 012027). IOP Publishing.

Prakash, C., \& Barua, M. K. (2015). Integration of AHP-TOPSIS method for prioritizing the solutions of reverse logistics adoption to overcome its barriers under fuzzy environment. Journal of Manufacturing Systems, 37, 599-615.

Rokicki, B., \& Stępniak, M. (2018). Major transport infrastructure investment and regional economic development-An accessibility-based approach. Journal of Transport Geography, 72, 36-49.

Roy, T., \& Dutta, R. K. (2018). Integrated fuzzy AHP and fuzzy TOPSIS methods for multi-objective optimization of electro discharge machining process. Soft Computing, 23(13), 5053-5063.

Shahraki, A. A. (2017). Regional development assessment: Reflections of the problem-oriented urban planning. Sustainable Cities and Society, 35, 224-231.

Singh, P. K., \& Sarkar, P. (2019). A framework based on fuzzy AHP-TOPSIS for prioritizing solutions to overcome the barriers in the implementation of ecodesign practices in SMEs. International Journal of Sustainable Development \& World Ecology, 1-16. https://doi.org/10.1080/13504509.2019.1605547

Sirisawat, P., \& Kiatcharoenpol, T. (2018). Fuzzy AHP-TOPSIS approaches to prioritizing solutions for reverse logistics barriers. Computers \& Industrial Engineering, 117, 303-318.

Sun, C. C. (2010). A performance evaluation model by integrating fuzzy AHP and fuzzy TOPSIS methods. Expert Systems with Applications, 37, 7745-7754.

Taylan, O., Bafail, A. O., Abdulaal, R. M., \& Kabli, M. R. (2014). Construction projects selection and risk assessment by fuzzy AHP and fuzzy TOPSIS methodologies. Applied Soft Computing, 17, 105116.

Teniwut, W. A., Teniwut, Y. K., Teniwut, R. M., \& Hasyim, C. L. (2017a). Family vs village-based: Intangible view on the sustainable of seaweed farming. In IOP Conference Series: Earth and Environmental Science (Vol. 89, No. 1, p. 012021). IOP Publishing.

Teniwut, W. A., Betaubun, K. D., \& Djatna, T. (2017b). A conceptual mitigation model for asymmetric information of supply chain in seaweed cultivation. In IOP Conference Series: Earth and Environmental Science (Vol. 89, No. 1, p. 012022). IOP Publishing.

Teniwut, W. A., \& Teniwut, R. M. (2018). Minimizing the instability of seaweed cultivation productivity on rural coastal area: a case study from Indonesia. Aquaculture, Aquarium, Conservation \& Legislation, 11(1), 259-271.

Teniwut, W., Marimin, M., \& Djatna, T. (2019). GIS-Based multi-criteria decision making model for site selection of seaweed farming information centre: A lesson from small islands, Indonesia. Decision Science Letters, 8(2), 137-150.

Turker, Y.A., Baynal, K., Turker, T. (2019). The evaluation of learning management systems by using Fuzzy AHP, fuzzy topsis and an integrated method: A case study. Turkish Online Journal of Distance Education (TOJDE), 20(2).

Vyas, G. S., Jha, K. N., \& Patel, D. A. (2019). Development of green building rating system using AHP and fuzzy integrals: A case of India. Journal of Architectural Engineering, 25(2), 04019004. 
Wang, J. J., Jing, Y. Y., Zhang, C. F., \& Zhao, J. H. (2009). Review on multi-criteria decision analysis aid in sustainable energy decision-making. Renewable and Sustainable Energy reviews, 13(9), 22632278.

Zhang, J. (2009). Technology and regional development. International Encyclopedia of Human Geography, 171-176.

Zyoud, S. H., \& Fuchs-Hanusch, D. (2017). A bibliometric-based survey on AHP and TOPSIS techniques. Expert Systems with Applications, 78, 158-181.

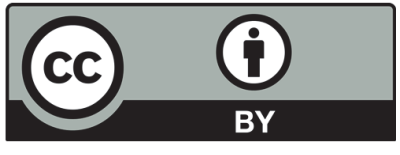

(C) 2019 by the authors; licensee Growing Science, Canada. This is an open access article distributed under the terms and conditions of the Creative Commons Attribution (CC-BY) license (http://creativecommons.org/licenses/by/4.0/). 